\title{
Is there a resumption of political psychiatry in the former Soviet Union?
}

\author{
Robert van Voren
}

Chief Executive of the Federation Global Initiative on Psychiatry; Professor of Political Science, Vytautas Magnus University, Kaunas, Lithuania, and Ilia State University, Tbilisi, Georgia

There is no declared interest of the author other than his stance on human rights. In 2013 the European Parliament published turs his repot on the issue of the resumption of the political abuse of psychiatry in the former Soviet republics: Psychiatry as a Toll of Coercion in Post-Soviet Countries (16 July 2013). Directorate General for External Policies, European Parliament, EXPO/B/ DROI/2013/02

\begin{abstract}
After the outbreak of the Ukrainian crisis in the spring of 2014, the former Soviet Union again became front-page news. The sequence of events led to an atmosphere reminiscent of the Cold War. In Russia itself it led to a hunt for 'national traitors' and 'foreign agents' and observers both inside the country and abroad fear a return to Soviet-style repression. For the outside world this may come as a surprise, but human rights activists have been ringing the alarm bells for a few years. Ever since Vladimir Putin took power, the human rights situation has deteriorated. One of the warning signs was the return of the use of psychiatry for political purposes, to 'prevent' social or political activism or to ostracise an activist.
\end{abstract}

\section{What is political abuse of psychiatry?}

Political abuse of psychiatry refers to the misuse of psychiatric diagnosis, treatment and detention for the purposes of obstructing the fundamental human rights of certain individuals and groups in a given society. The practice is common in, but not exclusive to, countries governed by totalitarian regimes. In these regimes, abuses of the human rights of those politically opposed to the state are often hidden under the guise of psychiatric treatment. In democratic societies 'whistle-blowers' on covert illegal practices by major corporations have been subjected to the political misuse of psychiatry.

The Soviet Union was a country where political abuse of psychiatry took place, but over the past decades quite extensive documentation has been published on similar abuses in other countries as well. ${ }^{1}$ The fact that the use of psychiatry for political purposes is reported from so many diverse

\footnotetext{
${ }^{1}$ There were extensive reports on the systematic political abuse of psychiatry in Romania, and also reports on individual cases in Czechoslovakia, Hungary and Bulgaria but without evidence of systematic abuse. Research on East Germany came to the latter conclusion, although politics and psychiatry appeared to have been closely intermingled. Later, information appeared on the political abuse of psychiatry in Cuba, and there are frequent reports on systematic abuse of psychiatry for political purposes in the People's Republic of China. In the 1990s, a case of political abuse of psychiatry took place in The Netherlands, in the course of which the Ministry of Defence tried to silence a social worker by falsifying several of his psychiatric diagnoses and pretending his behaviour was the result of mental health problems. See IAPUP (1989), Süss (1998), Brown \& Lago (1991), Munro (2001, 2006), Nijeboer (2006).
}

countries reveals an ongoing tension between politics and psychiatry, and also that using psychiatry to stifle opponents or to solve conflicts appeals not only to dictatorial regimes but also to well established democratic societies. Nevertheless, it is clear that the political use of psychiatry has been a favourite of collectivist (socialist or communist) regimes. An explanation might be that ideologies that envision ideal societies - where all are equal and all will be happy - often conclude that those who oppose this must be of an unsound mind. ${ }^{2}$

\section{Soviet psychiatric abuse}

The use of psychiatry to incarcerate dissidents in psychiatric hospitals in the Soviet Union started to have a systematic character in the late 1950s and early 1960s. However, there are cases of political abuse of psychiatry known from much earlier. Nonetheless, in the course of the 1960s the political abuse of psychiatry in the Soviet Union became one of the main methods of repression. By the end of that decade many well-known dissidents were diagnosed as being mentally ill. According to our data, approximately one-third of all political prisoners were diagnosed as being 'mentally ill'. A crucial role in this was played by KGB Chairman Yuri Andropov, who in 1967 took the helm of that organisation and made the struggle against 'ideological diversion' the centrepiece of his KGB work. According to a former general in the Ukrainian KGB, it was Andropov who, together with a selected group of associates, developed the political abuse of psychiatry as a systematic means of repression (see, among others, Bloch \& Reddaway, 1977; van Voren, 2010).

The political abuse of psychiatry in the Soviet Union developed within a totalitarian

\footnotetext{
${ }^{2}$ It is also important to note that political abuse of psychiatry stands out from general abusive practices in psychiatry. The latter include general human rights violations in mental institutions, such as adverse living conditions, abuse by staff, unlawful incarceration, inhumane treatment, as well as 'economic abuse' of psychiatry. There is also a vast 'grey area' involving people who are hospitalised simply because they are considered bothersome, as well as people who do suffer from mental health problems but who should never have been compulsorily treated or hospitalised. This was the case in the Soviet Union and is presently the case in China, where many victims are so-called 'petitioners', who travel to Beijing from the provinces in order to issue complaints against local officials. Instead of being heard they are hospitalised and frightened with psychiatric 'treatment'.
} 
environment, which greatly facilitated its growth. The diagnosis of 'sluggish schizophrenia', developed by the Moscow School of Psychiatry and in particular by academician Andrei Snezhnevsky, provided a handy framework to explain this behaviour. According to the theories of Snezhnevsky, schizophrenia was much more prevalent than previously thought, because the illness could be present with relatively mild symptoms and progress only later. According to Snezhnevsky, patients with sluggish schizophrenia were able to function almost normally in the social sense. Their symptoms could resemble those of a neurosis or could take on a paranoid quality. Patients with paranoid symptoms retained some insight into their condition, but overvalued their own importance and might exhibit grandiose ideas of reforming society. Thus, symptoms of sluggish schizophrenia could be 'reform delusions', 'struggle for the truth' and 'perseverance' (see Bloch, 1989).

\section{The post-Soviet period}

When in 1991 the Soviet Union imploded, all 15 Soviet republics gained or regained their independence. Some did this with considerable success, others with a long list of hiccups, fallbacks and periods of civil war, bouts of despotism or conflicts with neighbours. The collapse of the Soviet Union saw the development of a non-governmental sector in mental health. Until the late 1980s, Soviet psychiatry was dominated by one psychiatric association, the All-Union Society of Psychiatrists and Neuropathologists (AUSPN), which was directly controlled by the Ministry of Health of the Soviet Union (the stationery of the AUSPN even had the heading 'AUSPN' and then as a sub-heading 'Ministry of Health of the USSR'). In the course of the 1990s a dozen psychiatric associations were set up, as were professional bodies for, among others, psychiatric nurses; relatives' organisations were also established and, by the end of the century, the first groups of consumers of mental health services. A vibrant web of groups, committees and associations emerged that strived to humanise services.

The practice of using psychiatry against political opponents virtually ceased to exist, although a few cases surfaced, notably in 1996 in Turkmenistan and in Uzbekistan. What came in its place, however, was a very disturbing collection of other forms of abuse, including 'economic abuse' (e.g. having relatives declared mentally ill in order to take control of their property) and criminals avoiding incarceration by bribing psychiatrists to deliver false diagnoses. Furthermore, human rights abuses in the mental health system in the former Soviet republics remained rampant, due to lack of resources, outdated methods of treatment, lack of understanding of individual human rights and a growing lack of tolerance in society where survivalism became the main philosophy.

In Russia, the reform movement in mental health had only a limited impact. Many of the mental health institutions remained inhuman environments, while the level of psychiatric care was far from acceptable and knowledge about modern therapeutic approaches, the role of relatives and carers and the self-help capabilities of mental health service users remained scarce and limited. One of the main reasons for this situation was the fact that the leadership of Soviet psychiatry in Russia maintained its power base. Most leaders of Russian psychiatry also revoked the earlier confession that psychiatry in the Soviet Union had been abused systematically for political purposes and instead referred to 'individual cases of hyperdiagnosis' or 'academic differences of opinion' (Dmitrieva, 2001, pp. 116-130).

The number of individual cases of political abuse of psychiatry has increased significantly over the past few years, in particular in Russia, Belarus and Kazakhstan. So far it appears not to be yet a systematic repression of dissidents through the mental health system. In most cases, citizens fall victim to regional authorities in localised disputes, or to private antagonists who have the means to bribe their way through the courts.

The resumption of political abuse in individual cases is closely linked to the deteriorating human rights situation and the fact that lower-level authorities feel much more freedom to clamp down on undesired elements than previously. An air of untouchability is returning, and the rule of law has increasingly become subject to political machinations. In particular, in Russia much of the structure is still in place that allowed the political abuse of psychiatry to happen. The first cases of renewed political abuse of psychiatry started to emerge at the beginning of the 21st century, after Vladimir Putin resumed the Presidency and the downward spiral towards increased repression commenced (see e.g. Murphy, 2006).

\section{References}

Bloch, S. (1989) Soviet psychiatry and Snezhnevskyism. In Soviet Psychiatric Abuse in the Gorbachev Era (ed. R. van Voren), pp. 55-61. International Association on the Political Use of Psychiatry (IAPUP).

Bloch, S. \& Reddaway, P. (1977) Russia's Political Hospitals. Gollancz.

Brown, Ch. A. \& Lago, A. (1991) The Politics of Psychiatry in Revolutionary Cuba. Transaction Publishers.

Dmitrieva, D. (2001) Alyans Prava i Miloserdiya. [Alliance of Law and Compassion.] Nauka.

IAPUP (International Association on the Political Use of Psychiatry) (1989) Psychiatry Under Tyranny: An Assessment of the Political Abuse of Romanian Psychiatry During the Ceausescu Years. International Association on the Political Use of Psychiatry (IAPUP).

Munro, R. (2001) Judicial Psychiatry in China and Its Political Abuses. GIP.

Munro, R. (2006) China's Psychiatric Inquisition. Wiley, Simmonds \& Hill.

Murphy, K. (2006) Speak out. Are you crazy? Los Angeles Times, 30 May.

Nijeboer, A. (2006) Een man tegen de Staat. [One Man Against the State.] Papieren Tijger.

Süss, S. (1998) Politisch Missbraucht? Psychiatrie und Staatssicherheit in der DDR. [Politically Abused? Psychiatry and State Security of the GDR.] Links Verlag.

van Voren, R. (2010) Cold War in Psychiatry. Rodopi. 